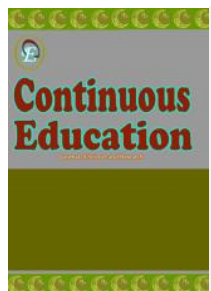

Continuous Education : Journal of Science and Research

Volume 2, Issue 2, July 2021

http://pusdikra-publishing.com/index.php/josr/home-free

Manajemen Strategi Hubungan Masyarakat dalam Meningkatkan Minat Calon Siswa Bersekolah di Yayasan Surban MTs Pacet Mojokerto

Mika Julianti

Institut Pesantren KH. Abdul Chalim, Pacet Mojokerto

Corresponding Author: mikajulianti33@gmail.com

\begin{tabular}{|c|c|}
\hline & ABSTRACT \\
\hline $\begin{array}{l}\text { ARTICLE INFO } \\
\text { Article history: } \\
\text { Received } \\
\text { 14 July } 2021 \\
\text { Revised } \\
\text { 24 July } 2021 \\
\text { Accepted } \\
\text { 28 July } 2021\end{array}$ & $\begin{array}{l}\text { The main objective of carrying out a public relations strategy management in an } \\
\text { educational institution is that the school continues to be in demand by educated } \\
\text { participants and experiences development and progress from year to year. In } \\
\text { conveying information, good communication is needed so that the information } \\
\text { submitted can be received. In conveying information, public relations must have } \\
\text { good strategic management and direction so that what is expected is carried out } \\
\text { well. Data collection techniques are carried out by observation, Interviews } \\
\text { and documentation. The results of this study indicate that: (1) Public Relations } \\
\text { Strategy Management in Increasing Student Interest in MTs Pacet Surban } \\
\text { Foundation includes planning, communicating, implementing and evaluating } \\
\text { well and directed by the school to attract the attention of prospective new } \\
\text { students. (2) One of the inhibiting factors for public relations in increasing the } \\
\text { interest of prospective students to attend the MTs Pacet Surban Foundation } \\
\text { includes ineffective time in the implementation of management as well as long } \\
\text { distances so that strategic management is not optimal. }\end{array}$ \\
\hline Keywords & Strategic Management, Public Relations, Student Interest \\
\hline How & $\begin{array}{l}\text { Mika Julianti. (2021). Manajemen Strategi Hubungan Masyarakat } \\
\text { dalam Meningkatkan Minat Calon Siswa Bersekolah di Yayasan } \\
\text { Surban MTs Pacet Mojokerto. Journal Continuous Education, 2(2). 46- } \\
\text { 58. 10.51178/ce.v2i2.232. }\end{array}$ \\
\hline
\end{tabular}

\title{
PENDAHULUAN
}

Pendidikan nasional merupakan suatu pendidikan yang menanamkan akan sebuah nilai-nilai yang menyangkut pada bidang keagama, kebudayaan yang tertuang dalam nilai Nasional Indonesia, serta akan selalu tanggap terhadap perubahan dalam suatu zaman yang didasarkan pada nilai-nilai yang terkandung dalam Pancasila dan UUD 1945. Pendidikan merupakan proses untuk meningkatkan, memperbaiki, serta mencetak manusia untuk selalu mengembangkan keterampilan melalui proses pengajaran dan pelatihan. Sekolah merupakan salah satu lembaga pendidikan yang mengarah pada pendidikan formal guna meningkatkan mutu pendidikan. Seluruh komponen serta perangkat yang ada di dalam suatu lembaga pendidikan diharapakan dapat memuasakan peserta didik dalam menuntut ilmu pengetahuan. 
Siswa merupakan komponen penting dalam dunia pendidikan selain sarana dan prasarana pendukung pendidikan. Minat siswa merupakan faktor penting sebagai penentu dalam memilih sekolah. Agar sekolah tersebut tetap diminati siswa tentunya diperlukan manajemen strategi dari pihak sekolah. Dalam pembahasan humas, pada lembaga sebuah lembaga pendidikan yang masih belum begitu difungsikan secara terarah dan tepat. Hal ini disebabkan karena kurangnya suatu informasi dan pengetahuan yang belum dimiliki dan tersampaikan kepada para pengelola atau sebagai tenaga pelaksana humas pada sebuah lembaga pendidikan tersebut.

Humas di dalam lembaga pendidikan tentunya memiliki posisi yang didominan sangat penting dalam sebuah instansi baik yang berupa dalam sebuah lembaga organisasi, perusahaan maupun lembaga- lembaga lainnya seperti sekolah. Tujuan yang tentunya hendak dicapai oleh humas ialah untuk wadah untuk menyebarkan sebuah informasi yang menciptakan dan memelihara serta dapat membina suatu hubungan yang sangat baik kepada masyarakat sehingga terjalin hubungan yang harmonis dan mendapat citra yang positif bagi sekolah dan masyarakat. Manajemen strategi humas harus terarah dan terencana dengan sebaik-baiknya.

\section{Manajemen Strategi}

Manajemen dalam bahasa inggris artinya to manage, yaitu mengatur atau mengelola, atau kegiatan yang dilakukan untuk mengelola lembaga atau organisasi. manajamen berkaitan dengan proses perencanaan, pengorganisasian, kepemimpinan dan pengendalian, yang di dalamnya terdapat upaya dari anggota organisasi untuk mencapai tujuan yang telah ditetapkan bersama (Hikmah, 2014). Dalam pandangan terhadap dunia pendidikan, manajemen merupakan suatu proses, sistem, dan proses dari pemecahan suatu masalah. Dalam memanajemen sebuah lembaga pendidikan yang perlu diperhatikan adalah mengenai tujuan, manusia, sumber dan juga waktu. Manajemen pendidikan merupakan subsistem dari lembaga pendidikan yang unsur-unsurnya terdiri dari unsur lembaga dan organisasi yang mengelola terhadap semua kebutuhan institusional dalam pendidikan dengan cara yang efektif dan efisien.

Manajemen merupakan suatu rangkaian kegiatan kepengurusan, ketatalaksanaan penggunaan sumber daya untuk mencapai sasaran atau tujuan pokok yang telah ditentukan dengan menggunakan orang-orang pelaksana dalam suatu hubungan kerjasama. Manajemen diartikan sebagai proses perencanakan (planning), mengorganisasi (organizing), Penggerakan (Actuating), dan mengendalikan (controlling). 
Defenisi manajemen strategi menurut Barney mengartikan sebagai proses pemilihan dan penerapan strategi secara keseluruhan mengenai penggunaan sumber daya untuk menciptakan posisi yang menguntungkan. Manajemen strategi adalah seni dan ilmu penyusunan, penerapan, dan pengevalusian keputusan lintas fungsional yang memungkinkan suatu perusahaan mencapai sasarannya, mengembangkan kebijakan dan perencanaan untuk mencapai sasaran, serta pengalokasian sumber daya untuk menerapkan kebijakan dan perencanaan pencapaian tujuan organisasi (Racmad, 2014).

Manajemen strategi terdiri atas tiga proses meliputi:

1) Pembuatan strategi, meliputi pengembangan misi dan tujuan jangka panjang, mengidentifikasi peluang dan ancaman dari luar serta kekuatan dan kelemahan lembaga pendidikan.

2) Penerapan strategi meliputi, penentuan sasaran operasional tahunan, kebijakan organisasi, pemotivasian anggota dan pengalokasian sumber daya.

3) Evaluasi/control strategi, mencangkup usaha-usaha untuk memotivator seluruh pembuatan dan penerapan strategi termasuk mengukur kinerja individu dan perusahaan serta mengambil langkah-langkah perbaikan.

Tujuan dari manajemen strategi adalah melaksanakan dan mengevalusi pemilhan kestrategian ini yang dipilih haruslah tepat secara keefektifan dan keefisienannya, selalu mengevaluasi kinerja kerja yang terarah, serta dapat selalu merumuskan dalam pengembangan yang ada pada lingkungan eksternal, selalu berupaya meninjau kembali kekuatan yang sudah ada, menekan pada titik kelemahan, memberikan peluang dan ancaman dimasa yang akan datang, dan selalu melakukan inovasi atas pencapaian suatu produk yang sesuai dengan yang telah diinginkan sebelumnya.

Dalam merumuskan sebuah strategi tidaklah mudah, makna terpenting dalam pemahaman strategi adalah mengambil sebuah tindakan yang berbeda dari lembaga pesaing lainnya guna mencapai posisi dan tujuan yang diinginkan. Strategi di dasarkan pada analisis yang terintegrasi dan holistik, maksudnya ialah setelah strategi disusun, semua unsur dan elemen yang ada di dalam pengorganisasian sudah menginternalisasikan visi, misi secara baik dan benar.

Manajemen strategi bertugas mengendalikan proses panjang, mengangkat dan menempatkan orang-orang yang terkait dalam proses itu. Manajemen strategi adalah seni dan ilmu penyusunan, penerapan, dan pengevalusian keputusan lintas fungsional yang memungkinkan suatu perusahaan mencapai 
sasarannya, mengembangkan kebijakan dan perencanaan untuk mencapai sasaran, serta pengalokasian sumber daya untuk menerapkan kebijakan dan perencanaan pencapaian tujuan organisasi.

\section{Manajemen Strategi Hubungan Masyarakat}

Humas dapat diartikan sebagai sebuah ilmu seni sekaligus juga bisa dikatakan sebagai suatu ilmu sosial yang digunakan dalam menganalisa suatu sistem kecenderungan yang digunakan untuk meramalkan bagaimana konsekuensinya dalam sebuah sistem, yang digunakan dalam memberikan pengarahan kepada pimpinan sebuah institusi/lembaga dalam melaksanakan program-program yang telah terencana yang dapat memenuhi kepentingan baik pada sebuah institusi lembaga tersebut maupun kepada masyarakat yang terkait (Abdul, 2016).

Menurut Cultip, Center dan Broom humas adalah fungsi manajemen yang bertujuan untuk membangun dan mempertahankan hubungan baik antara organisasi dan publik yang memberikan dampak positif terhadap keberhasilan dan kegagalan sebuah organisasi. Dalam memberikan sebuah informasi humas lah yang bertanggung jawab akan hal tersebut, selain memberikan sebuah informasi humus juga berperan penting dalam mendidik, meyakinkan orang lain, meraih simpati atas apa yang menjadi tujuan yang hendak dicapai kepada orang lain tersebut, dan membangkitkan serta menumbuhkan rasa ketertarikan masyarakat terhadap sesuatu atau serta dapat membuat masyarakat mengerti dan menerima sebuah situasi yang di informasikan (Rachmadi, 1996).

Humas adalah segala bentuk kontak dan hubungan yang diadakan oleh suatu organisasi dengan semua bentuk publik baik internal maupun eksternal, yang meliputi semua bentuk komunikasi. Unsur terbentuknya komunikasi yang baik di dalam humas harus meliputi: 1) fungsi manajemen, 2) fungsi komunikasi, 3) fungsi penelitian dan penilaian, 4) suatu fungsi yang dirancang untuk meningkatkan saling pengertian, keserasian, dan masukan yang demokratis ke dalam suatu proses pengambilan keputusan.

Permendiknas No. 24 Tahun 2008 tentang Standar Tenaga Admnistrasi Sekolah/Madrasah, Tugas Pelaksanaan Administrasi Hubungan Sekolah dengan Masyarakat yaitu: (a) Mengatur hubungan sekolah dengan orang tua, (b) Memelihara hubungan baik dan memfasilitasi kelancaran kegiatan dengan komite sekolah, (c) Membantu dalam merencanakan suatu program yang melibatkan stakeholders yang ada didalmnya, (d) selalu membina kerjasama yang baik antara lemabga dengan Pemerintah serta lembaga-lembaga yang terdapat didalam lapisan masyarakat, (e) Selalu mempromosikan sekolah/madsarah yang dijadikan sebagai tujuan dari lembaga tersebut, (f) Lembaga atau istansi diharapkan dapat 
mengkoordinasikan penelusuran kepada lulusan (alumni) yang telah lulus dari lembaga tersebut, g) Selalu memberikan pelayanan terbaik terhadap tamu sekolah/ madrasah tersebut, (h) Membuat layanan sistem informasi yang terbaik dan selalu memberikan laporan tentang bagaimana hubungan sekolah dengan masyarakat tersebut, (i) Dalam menjaga hubungan yang baik kepada masyarakat sekolah harus semaksimal mungkin memanfaatkan TIK dalam proses pengadmisitrasiannya (j) M Tehnik komunikasi yang harus ada dalam sebuah lembaga agar informasi yang disampaikan diterima dan tersampaikan dengan baik kepada masyarak harus lah sistematis seperti (majalah, surat kabar dan mendatangkan sumber yang lainnya).

Tujuan utama Public Relation yang terdapat diatas merupakan sebuah tujuan yang hendak capai diantaranya: (a) Mengevaluasi sikap dan opini public, (b) Formulasi dan implementasi prosedur organisasi atas komunikasi organisasi/perusahaan dengan publik, (c) Mengkoordinasikan program-program komunikasi, (d) Mengembangkan hubungan komunikasi dua arah mengembangkan hubungan positif antar organisasi dan publik.

Manajemen merupakan sistem pengelolaan yang sangat diperlukan, jika tidak termanajemen dengan baik maka tidak akan berhasil serta haruslah dilaksanakan sesuai dengan strategi yang sesuai, strategi yang baik dan efektif diantaranya meliputi: distingtif, fokus, reputasi dan identitas (Rosalina: 2015: 40). Dalam melaksanakan sebuah strategi dimana humas harus lah difungsikan dengan baik dalam memperkenalkan sebuah lembaga kepada elemen masyarakat dan tentunya diharpakan mampu menarik minat masyarakat. hal tersebut dapat dilakukan dengan menggunkaan sistem kegiatan yang dilakukan secara langsung maupun dilakukan dengan kegiatan yang tidak langsung.

Tujuan dari manajemen strategi adalah melaksanakan dan mengevalusi strategi yang dipilih secara efektif dan efisien, mengevaluasi kinerja, merumuskan pengembangan lingkungan eksternal, meninjau kembali kekuatan, kelemahan, peluang dan ancaman, dan melakukan inovasi atas produk sesuai dengan yang diinginkan konsumen.

Adapun tugas dan kewajiban dari Humas adalah:

a. Menyampaikan pesan atau informasi dari lembaga secara lisan, tertulis atau visual kepada publiknya, sehingga masyarakat atau publik memperoleh pengertian yang benar dan tepat mengenai kondisi lembaga, tujuan dan kegiatanya.

b. Melakukan studi dan analisis atas reaksi serta tanggapan publik terhadap kebijakan dan langkah tindakan lembaga, termasuk segala macam pendapat publik yang mempengaruhi lembaga, memberi informasi kepada 
pejabat (eksekutif) tentang Public Acceptance atau Non Acceptance atas caracara pelayanan lembaga kepada masyarakat.

c. Menyampaikan fakta-fakta dan pendapat kepada para pelaksana tugas guna membantu mereka dan memberikan pelayanan yang mengesankan dan memuaskan publik.

\section{Manajemen Strategi Hubungan Masyarakat dalam Dunia Pendidikan}

Defenisi manajemen strategi humas menurut Ruslan, merupakan sebuah proses yang digunakan dalam penanganan suatu perencanaan, pengorganisasian, pengkomunikasian serta pengkoordinasian yang mana tahapan demi tahapan dilakukan secara penuh keseriusan dan rasional agar upaya yang dilakukan dapat mencapai tujuan bersama dari kegiatan organisasi yang dilakukan oleh sebuah lembaga atau yang diwakilinya (Harini, 2014).

Defenisi menurut para ahli, Hunger dan Wheelen mendefinisikan manajemen berbasis sekolah strategi adalah seperangkat keputusan dan aksi yang menentukan kinerja panjang organisasi, yang meliputi scaning lingkungan, perumusan strategi (perencanaan strategi), pelaksanaan strategi serta pengendalian dan evaluasi (Akdon, 2016).

Defenisi manajemen strategi hubungan masyarakat yang di kemukakan oleh, Brown \& Mark Manajemen berarti penelitian, perencanaan, pengkomunikasian, pelaksanaan dan pengevaluasian suatu kegiatan komunikasi yang disponsori oleh organisasi, mulai dari pertemuan kelompok kecil hingga berkaitan dengan konferensi press internasional via satelit, dari pembuatan brosur hingga kampanye nasional melalui multimedia, dari pengumuman pelayanan publik hingga menangani kasus manajemen krisis (Iriantara, 2014).

Manajemen strategi humas adalah upaya organisasi untuk bisa menyelaraskan dirinya dengan lingkungannya. Dalam mengelola organisasi tidak lagi memadai bila hanya mengandalkan intuisi, termasuk mengandalkan intuisi dalam menyusun siasat bisnis.

Manajemen public Relations merupakan sebuah penerapan fungsi-fungsi dasar manajemen, public relations berarti melakukan sebuah penelitian, suatu perencanaan, pelaksanaan yang ada di dalamnya dan evaluasi terhadap kegiatan komunikasi.

Menurut Ruslan yang dimaksud dengan publik internal adalah publik yang menjadi bagian dari unit/badan/perusahaan atau organisasi itu sendiri. Humas internal dikutip dari Suharsismi Arikunto meliputi: 1) Humas antara kepala dengan guru-guru. 2) Humas antara kepala dengan murid.3) Humas antara kepala dengan pegawai TU. 4) Humas antara guru-guru dengan murid. 5) Humas antara murid-murid dengan pegawai TU. 
Strategi humas dalam lingkup publik eksternal adalah publik umum (masyarakat). Mengusahakan tumbuhnya sikap dan gambaran publik yang positif terhadap lembaga yang diwakilinya. Hubungan masyarakat keluar (Humas Eksternal) turut menentukan keberhasilan kegiatan hubungan masyarakat suatu badan atau lembaga. Strategi humas yang berfungsi untuk memperkenalkan lembaga kepada masyarakat dan menarik minat masyarakat juga dapat dilakukan dengan kegiatan langsung dan kegiatan tidak langsung

\section{Minat Siswa}

Defenisi minat menurut para ahli, Whiteringte menyatakan minat merupakan kacendrungan seseorang akan sesutu yang menimbulkan keinginan untuk memilih sesuatu tersebut atau keinginan yang timbul untuk melakukan suatu kegiatan yang telah dipilih diantara sejumlah kegiatan kegiatan lainnya.

Defenisi minat menurut, Barbirn merupakan kesadaran diri dari seseorang terhadap suatu yang terdapat pada objek, atau suatu keadaan yang menimbulkan suatu hubungan yang penting terhadapnya. Minat merupakan respon sadar yang bernilai suatu makna yang terkandung di dalamnya (Barbirin, 1990). Minat terdiri dari kognitif dan afaktif, aspek kogniktif berupa konsep positif terhadap suatu objek dan berpusat pada manfaat dari objek tertentu. Aspek afaktif nampak dalam rasa suka atau tidak senang dan kepuasan pribadi terhadap objek tertentu.

Minat seseorang terkadang tidak timbul dengan sendirinya, harus ada unsur kebutuhannya. minat timbul dikarenakan ada beberapa faktor yang mempengaruhinya. Faktor yang mempengaruhi sehingga munculnya minat sesorang antara lain: 1). Dari diri individu sendiri, 2). Lingkungan (internal dan eksternal) (Rahman, 2004).

Berdasarkan pangertian di atas, peneliti menyimpulkan minat merupakan sambutan kesadaran atas ketertarikan terhadap suatu objek tertentu yang mempunyai suatu nilai tertentu. Dimana ketertarik seseorang terhadap sesuatu membuat seseorang akan memilih sesuatu tersebut sebagai salah satu keinginan yang timbul di dalam hati dan akhirnya memilih sesuatu tersebut sebagai bentuk keinginannya.

Berdasarkan studi pendahuluan yang dilakukan oleh peneliti terhadap informasi terkait manajemen strategi humas. Hasil wawancara pada saat peneliti melakukan observasi kepada salah satu narasumber yang merupakan kepala sekolah menunjukan bahwa terbantuknya humas di sekolah sebagai alat untuk menyampaikan informasi kepada calon peserta didik dan masyarakat sekitar. 
Berdasarkan asumsi yang peneliti temukan bahwa Yayasan Surban MTs Pacet belum membentuk struktur kehumasan dengan baik, hal ini ditunjukan dengan rendahnya minat peserta didik yang ditandai dengan adanya penurunan jumlah peserta didik dari tahun ketahun. Selain rendahnya minat calon peserta didik, humas di sekolah Yayasan Surban MTs Pacet juga belum terarah dan difungsikan dengan baik sesuai dengan fungsinya yaitu menarik minat calon peserta didik.

Penelitian yang dilakukan di Yayasan Surban MTs Pacet ini dilakukan untuk mengetahui bagaimana manajemen strategi hubungan masyarakat dalam meningkatkan minat siswa bersekolah di Yayasan Surban MTs Pacet Mojokerto.

\section{METODE PENELITIAN}

Jenis penelitian yang digunakan oleh peneliti adalah jenis penelitian kualitatif deskriptif, pendekatan yang digunakan oleh peneliti adalah jenis pendekatan studi kasus. Dimana dalam penelitian yang menggunakan kualitatif dibuat secara sistematis, faktual dan akurat terhadap fakta dan sifat populasi pada suatu daerah tertentu. Dalam pengumpulan data adapun teknik dalam pengumpulan data dilakukan dengan observasi yang dimulai dari sebuah pengamatan baik secara langsung terhadap segala sesuatu hal yang terjadi dilokasi penelitian. Dimana sebelum melakukan penelitian, peneliti melakukan observasi terlebih dahulu setelah itu melakukan pengamatan terhadap apa yang menjadi objek dalam penelitian serta melakukan pencatatan terhadap objek penelitian tersebut diatas (Sugiyono, 2007).

Setelah melakukan observasi dan menemukan masalah yang terjadi dilapangan, selanjutnya peneliti memulai penelitian dengan melakukan wawancara kepada objek yang dijadikan penelitian. Wawancara dilakukan peneliti dengan mengajukan pertanyaan secara langsung yang telah dipersiapkan terlebih dahulu sebelum diajukan kepada responden, dan setelah itu jawaban-jawaban responden terhadap pertanyaan dari peneliti dicatat dan atau direkam dengan alat perekam.

Adapun Informan yang dijadikan sumber informasi untuk mendapatkan data yang diinginkan peneliti dalam penelitian ini adalah seluruh organisasi yang terdapat di dalam sekolah diantaranya: Kepala Sekolah, Waka Kehumasan, Orang Tua dan Siswa. Setelah selesai melakukan wawancara langka selanjutnya yang peneliti gunakan adalah dengan melakukan tehnik dokumentasi. Dimana teknik dokumentasi ini peneliti gunakan adalah untuk melengkapi dan mendukung data yang diperolah dari hasil observasi dan wawancara. 
Setelah data didapat dan dinilai sudah lengkap, langkah selanjutnya yang digunakan peneliti adalah melakukan analisis data. dimana dalam menganalisis sebuah data peneliti menggunakan teknik analisis data yang terdapat pada teori dengan menggunakan model Miles dan Hubberman, yang meliputi analisis data reduction, data display dan conclusion drawing/verification. Setelah data selesai di analisis dalam Pengecekan keabsahan data peneliti menggunakan teknik triangulasi. Dimana tehnik triangulasi adalah sebagai salah satu teknik yang digunakan untuk meningkatkan kepercayaan peneliti dalam memahami sebuah fenomena yang terjadi selama proses penelitian berlangsung dan dapat dijadikan kajian dalam mengungkap sebuah temuan yang unik yang ditemukan selama penelitian berlangsung serta mengintrogasikannya pada sebuah teori yang digunakan dalam penelitian dan dapat memberi pemahaman yang jelas tentang masalah yang diteliti selama penelitian berlangsung.

\section{HASIL PENELITIAN DAN PEMBAHASAN}

\section{Manajemen Strategi Hubungan Masyarakat}

Berdasarkan temuan yang diperoleh dari hasil wawancara beberapa sumber bahwa manajemen strategi hubungan masyarakat dilakukan atas dasar untuk menambah minat calon siswa baru. Kondisi di lapangan menunjukan bahwa teori ini sejalan dengan teori manajemen strategi hubungan masyarakat yang dikemukakan oleh Brown \& Mark Manajemen berarti penelitian, perencanaan, pengkomunikasian, pelaksanaan dan pengevaluasian suatu kegiatan komunikasi yang disponsori oleh organisasi, mulai dari pertemuan kelompok kecil hingga berkaitan dengan konferensi press internasional via satelit, dari pembuatan brosur hingga kampanye nasional melalui multimedia, dari pengumuman pelayanan publik hingga menangani kasus manajemen krisis.

\section{a. Perencanaan}

Berdasarkan penemuan yang peneliti diperoleh dari hasil wawancara beberapa sumber bahwa manajemen strategi hubungan masyarakat bahwa perencanaan dilakukan agar terlaksana dan tersusun dengan baik. Kondisi di lapangan menunjukan bahwa teori ini merujuk pada teori yang dikemukakan oleh Monde dan Premeux bahwa perencanaan tersusun dan disusun berbagai pada sebuah visi, misi, yang berhubungan dengn tujuan serta sasaran yang harus dicapai yang tersusun dan terencana pada keputusan tingkat awal yang menggunakan dalam proses pengambilan keputusan tersebut. Dimana kondisi di lapangan perencanaan di mulai dengan rapat agar perencanaan dalam 
menyusun program rutin kerja, alat dan media apa saja yang dibutuhkan dan siapa saja yang terlibat di dalamnya.

\section{b. Pengkomunikasian}

Komunikasi merupakan aktivitas dalam menyampaikan informasi baik berupa pesan, ide serta gagasan dari pihak satu kepada pihak lainnya. Dalam hal ini dimana Humas di MTs Pacet sudah menjalin komunikasi dengan baik pada guru, siswa baik yang terdapat dilingkup sebuah sekolah dan di luar lingkup sebuah sekolah. Komunikasi dilakukan oleh humas bertujuan agar terjalinnya talisiraturahmi yang baik antara MTs Pacet dan lembaga Sekolah seperti SD dan MI.

\section{c. Pelaksanaan}

Dalam melaksanaan sebuah program kerja humas sangat lah berperan aktif dalam mendukung sebuah keberhasilan dari program kerja, Humas melibatkan diri dari keterkibatan terhadap seluruh elemen pendukung diantaranya kepala sekolah selaku penanggung jawab, guru dan siswa. Pelaksanaan merupakan suatu tindakan yang nyata bagi humas dalam hal mempromosikan sekolah agar dapat terlaksana sesuai dengan perencanaan yang telah ditetapkan secara efektif dan efisien. Strategi ini digunakan humas untuk memperkenalkan bagaimana Sekolah MTs Pacet ini dalam hal menarik minat masyarakat luas bukan hanya yang ada dilingkup Pacet saja tetapi diluar lingkup Pacet bisa melihat bagaimana MTs Pacet ini. Dalam akun facebook dimana seluruh kegiatan-kegiatan yang ada di MTs Pacet ini dimuat di dalam akun tersebut.

Selain mengunakan metode langsung dan tidak langsung MTs Pacet juga menggunakan strategi pencitraan. Dimana strategi ini digunakan sebagai salah satu upaya untuk menciptakan bagimana mendapat citra positif yang terdapat pada lingkungan masyarakat dan program tersebut dijalankan dan dapat serta menimbulkan kesan yang baik dimata masyarakat tersebut.

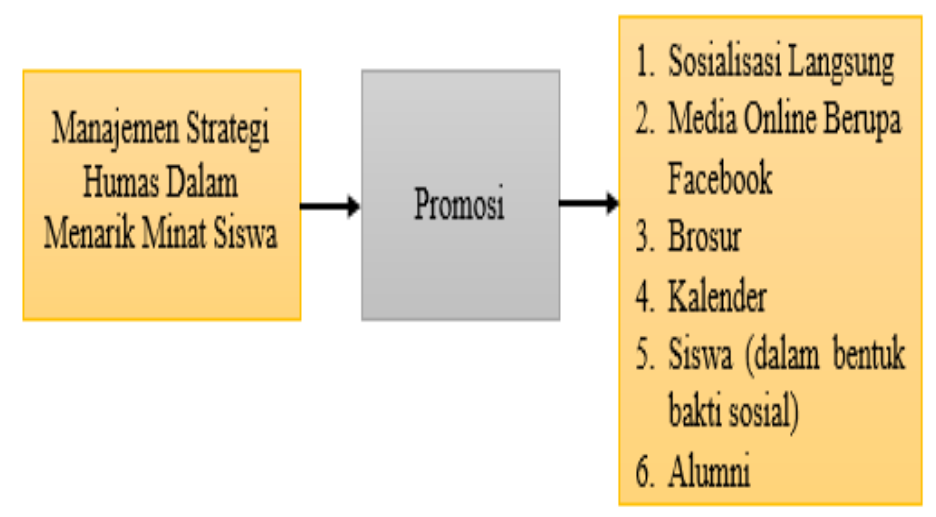




\section{d. Pengevaluasian}

Evaluasi perlu dilakukan untuk mengetahui sejauh mana keberhasilan dan hambatan apa saja yang dialami selama kegiatan berlangsung. Berdasarkan hasil penelitian, dimana peneliti menemukan bahwa evaluasi manajemen strategi Humas di MTs Pacet ini dilakukan setelah program-program kerja humas dilaksanakan. Evaluasi Humas di MTs Pacet ini bertujuan untuk melihat tingkat keberhasilan dari program kerja yang telah dilaksanakan.

\section{Faktor Penghambat Manajemen Strategi Hubungan Masyarakat}

Berdasarkan hasil penelitian yang didaptkan dilapangan, dimana terdapat beberapa faktor penghambat manajemen strategi Humas yang menyebabkan menurunya minat siswa bersekolah di MTs Pacet. Sebagaimana hal tersebut terdapat di dalam teori yang dikemukakan Rowe mengenai manajemen strategi yang terdapat peluang dan ancaman yang ada di dalammnya. Faktor tersebut meliputi: waktu, jarak lokasi dan banyaknya sekolah baru yang mulai beroperasi.

\section{a. Waktu}

Dalam menjalankan program pelaksanaan, humas harus bisa mengalokasikan waktu yang sesuai agar pelaksanaan dapat berjalan dengan baik. Berdasarkan dari hasil penelitian yang peneliti temukan di MTs Pacet waktu pelaksanaan program kerja humas dalam mempromosikan sekolah hanya pada waktu memasuki tahun ajaran baru saja. Kendala yang dihadapi humas pada saat pelaksanaan program kerja yaitu siswa dan guru. Dimana saat sosialisasi ke sekolah humas melibatkan guru dan siswa di Sekolah MTs untuk membantu proses sosialisasi ke lembaga Sekolah SD dan MI agar program sekolah dapat terlaksana dan tersampaikan sesuai dengan harapan.

Pada saat proses sosialisasi berlangsung, dimana siswa dan guru yang terlibat dalam sosialisasi ke lembaga Sekolah SD dan MI harus meninggalkan jam pelajaran di kelas. Hal ini tentunya dianggap sebagai suatu kendala bagi sekolah dikarenakan pada saat sosialisasi menggunakan waktu siswa di sekolah.

\section{b. Jarak lokasi}

Selain waktu faktor penghambat manajemen strategi humas yaitu mengenai jarak lokasi sekolah SD dan MI. Dimana berdasarkan dari hasil penelitian Humas di MTs Pacet ini hanya mensosialisasikan program sekolah ke lembaga-lembaga SD dan MI yang terdekat saja. Hal ini disebabkan karena perhitungan waktu dan biaya dan rata-rata siswa-siswi yang masuk ke Sekolah MTs ini hanya mereka yang memiliki jarak yang cukup dekat antara dan dengan Sekolah MTs ini saja. Sehingga untuk 
Sekolah SD dan Mi yang jaraknya jauh dari Sekolah MTs Pacet ini tidak pernah mensosialisasikannya secara langsung.

\section{KESIMPULAN}

Berdasarkan uraian paparan informasi data di atas dan dari hasil temuan selama penelitian serta pembahasan maka peneliti menarik beberapa kesimpulan untuk menjawab setiap fokus dan tujuan dari penelitian. Kesimpulan ini untuk mengetahui manajemen strategi Humas di MTs Pacet. Hasil kesimpulan yang dapat peneliti tarik adalah sebagai berikut:

1. Manajemen strategi yang dilakukan oleh Humas di Yayasan Surban MTs Pacet dalam meningkatkan minat siswa antara lain:

a. Melakukan sosialisasi langsung kesekolah-sekolah SD dan MI, dengan mendatangkan guru dan perwakilan siswa-siswi MTs Pacet.

b. Melakukan promosi sekolah melalui media online berupa facebook.

c. Melakukan promosi sekolah melalui media cetak berupa brosur dan kalender

d. Melakukan Promosi melalui siswa, guru dan alumni MTs Pacet.

Sebelum melakukukan promosi sekolah kepada siswa selaku sasarannya dimana Humas di MTs Pacet terlebih dahulu melakukan Perencanaan dengan sistem rapat, Pengkomunikasian dengan pihak sekolah dan luar sekolah yang dijalin dengan baik, Pelaksanaan yang melibatkan siswa dan guru yang ada di sekolah dan Evaluasi yang dilaksanakan sertiap akhir dari kegiatan.

2. Adapun faktor penghambat manajemen strategi Humas dalam meningkatkan minat siswa, yaitu: faktor waktu, jarak lokasi dan banyaknya sekolah baru yang didirikan/beroperasi sebagai kompetetor.

Selain faktor penghabat, terdapat juga faktor pendukung di dalamnya. Dimana dalam pelaksanaan manajemen strategi humas sekolah harus mendukung penuh setiap kegiatan yang akan dilaksanakan. Humas di MTs Pacet mendapat dukungan penuh dari sekolah seperti biaya operasional selama proses sosialisasi berlangsung serta peralatan dan media yang dibutuhkan oleh humas selama proses sosialisasi dan promosi berlangsung.

\section{DAFTAR PUSTAKA}

Rachmad, Manajemen Strategik, (Bandung: CV Pustaka Setia, 2014)

Sugiyono, Metode Penelitian Pendidikan Pendekatan Kualitatif, Kuantitatif dan RED, (Bandung: Alfabeta, 2007)

Irawan Soehartono, Metode Penelitian Sosial, (Bandung: Remaja Rosdakarya, 1999) 
Journal Continuous Education

Volume 2, Issue 2, July 2021

Page 46-58

Akdon, Strategic Management For Educational Management (Manajemen Strategic Untuk Manajemen Pendidikan), (Alfabeta: Bandung, 2006)

Yosal Iriantara, Manajemen Strategis Public Relations, (Jakarta: Ghalia Indonesia, 2004)

Yuke Rahmawati, "Manajemen Public Relations Sebagai Alat Etika Komunikasi dalam Bisnis Islam", Salam; Jurnal Filsafat dan Budaya Hukum - 183

Lilis Yulianti, Jurnal Walisongo (Faktor-Faktor Yang Mempengaruhi Minat Masyarakat), Volume 19, Nomor 1, Mey 2011, 110

Raminah Barbirin, Teori dan Apresiasi Puisi (Semarang: IKIP Semarang Pres, 1990)

Ujang Didi Supriyadi, Jurnal Ilmu Pendidikan (Pelaksanaan BOS dan Minat Masyarakat Mengikuti Pendidikan Dasar Gratis. Jilid 7. Nomor 1, Februari 200,80 .

Shaleh Abdul Rahman, Muhbibi Abdul Wahab, Psikologi Suatu Pengantar (Dalam Prespektif Islam), (Jakarta: Prenada Media, 2004)

Abdul Rahmad, Manajemen Humas Sekolah, (Yogyakarta: Media Akademi, 2016)

Rachmadi, Public Relations, (Jakarta: PT Gramedia Pustaka Utama, 1996)

Uraian Tugas Pokok Tenaga Administrasi (Berdasarkan Permen Diknas RI No. 24

Tahun 2008 Tentang Standart Tenaga Adminstrasi Sekolah).

Rosalina Nurizal Andi, Manajemen Hubungan Masyarakat dalam Menarik Minat Masyarakat di SMK 2 Ponorogo "Tesis", (Universitas Islam Negeri Maulana Malikibrahim: Malang), 40.

Anwar Yahya, Upaya Sekolah dalam Meningkatkan Animo Siswa Bersekolah di SMK Perkebunan MM 52 Yogyakarta (Tesis), 28.

Ira Nur Harini, "Manajemen Hubungan Masyarakat dalam Upaya Peningkatan Pencitraan Sekolah (Studi Kasus di SMP Al-Hikmah Surabaya)", Jurnal Inspirasi Manajemen Pendidikan, Vol. 4 No. 4, April 2014, 12. 